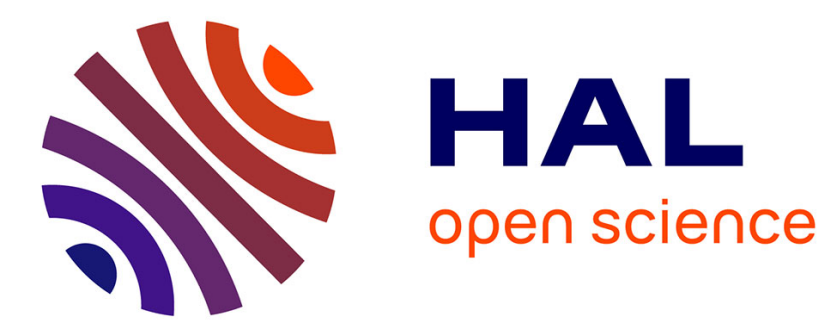

\title{
Measurement of AMPK-Induced Inhibition of Lipid Synthesis Flux in Cultured Cells.
}

\author{
Marc Foretz, Benoit Viollet
}

\section{To cite this version:}

Marc Foretz, Benoit Viollet. Measurement of AMPK-Induced Inhibition of Lipid Synthesis Flux in Cultured Cells.: Measurement of de novo lipogenesis. Methods in Molecular Biology, 2018, 1732, pp.363-371. 10.1007/978-1-4939-7598-3_23. inserm-01724353

HAL Id: inserm-01724353 https://www.hal.inserm.fr/inserm-01724353

Submitted on 6 Mar 2018

HAL is a multi-disciplinary open access archive for the deposit and dissemination of scientific research documents, whether they are published or not. The documents may come from teaching and research institutions in France or abroad, or from public or private research centers.
L'archive ouverte pluridisciplinaire $\mathbf{H A L}$, est destinée au dépôt et à la diffusion de documents scientifiques de niveau recherche, publiés ou non, émanant des établissements d'enseignement et de recherche français ou étrangers, des laboratoires publics ou privés. 
Measurement of AMPK-induced inhibition of lipid synthesis flux in cultured cells

Marc Foretz ${ }^{1,2,3, *}$ and Benoit Viollet ${ }^{1,2,3}$

${ }^{1}$ INSERM, U1016, Institut Cochin, Paris, France

${ }^{2}$ CNRS, UMR8104, Paris, France

${ }^{3}$ Université Paris Descartes, Sorbonne Paris Cité, France

Running head: Measurement of de novo lipogenesis

* Correspondence: marc.foretz@inserm.fr 


\begin{abstract}
AMP-activated protein kinase (AMPK) is a master regulator of multiple cellular metabolic pathways, including lipid metabolism. One of the well-known substrates of AMPK are acetyl CoA carboxylase (ACC) and 3-hydroxy-3-methylglutaryl-coenzyme A (HMGCoA) reductase, regulatory enzymes of fatty acid and cholesterol synthesis, respectively. The discovery that both of them are inactivated by AMPK suggested the therapeutic potential of AMPK activation in the treatment of metabolic diseases associated with lipid disorders, such as non-alcoholic fatty liver disease (NAFLD). Here we describe a method to measure lipid synthesis flux in intact cells from the saponifiable (including fatty acids) and non-saponifiable (including sterols) fractions of lipid extracts.
\end{abstract}

Key words: AMP-activated protein kinase, lipogenesis, lipid synthesis, fatty acid synthesis, sterol synthesis, indirect AMPK activators, small molecule AMPK activators, metformin. primary hepatocytes, AMPK knockout 


\section{1- Introduction}

The regulation of cellular energy metabolism by AMP-activated protein kinase (AMPK) activation is achieved by acute phosphorylation of key enzymes in carbohydrate, lipid and protein metabolism [1].. In the liver, AMPK activation influences several downstream cellular targets involved in fatty acid and cholesterol synthesis. Acetyl-CoA carboxylase (ACC) and 3-hydroxy-3-methylglutaryl-coenzyme A reductase (HMG-CoA reductase), key enzymes in fatty acid and cholesterol synthesis, respectively, were the first two enzymes shown to be phosphorylated and inhibited by AMPK $[2,3]$. AMPK inhibits hepatic fatty acid synthesis through the phosphorylation of ACC1 at Ser79, leading to its inactivation and thus determining cytosolic concentrations of the reaction product malonyl-CoA, a key precursor for the generation of new fatty acids [4]. Given these properties, it is not surprising that AMPK has emerged as an attractive therapeutic target for pathological conditions characterized by abnormal hepatic lipid accumulation, such as non-alcoholic fatty liver disease (NAFLD) [5]. Interestingly, recent studies also challenged the therapeutic potential for AMPK activation to limit tumour cell growth and restrict viral replication by inhibiting the cellular lipid accumulation [6-8]. We and others have demonstrated that single and dual treatment with indirect and direct AMPK activators increases ACC phosphorylation leading to the inhibition of de novo lipogenesis in primary hepatocytes [9-14]. Here, we describe a detailed protocol for testing the potential of various pharmaceuticals/nutraceuticals compounds on lipid metabolic flux in cultured cells. The quantitative evaluation of lipid synthesis flux is realized by the use of radiolabeled $\left[1-{ }^{14} \mathrm{C}\right]$-acetate tracer and monitoring the amount of radioactivity into the lipid fractions. Analysis of the saponifiable and non-saponifiable fractions of lipid extracts enables the quantification of fatty acids and sterols synthesis flux, respectively. 


\section{2- Materials}

2.1.. Cell culture

1. Mouse primary hepatocytes. (see Note 1).

2. Cell culture plasticware (6 well plates)

3. Hepatocyte culture medium: Medium 199, $100 \mathrm{nM}$ Dexamethasone, 100 units/mL penicillin, $100 \mu \mathrm{g} / \mathrm{mL}$ streptomycin. Store at $4^{\circ} \mathrm{C}$. (see Notes 2 and 3).

4. $\left[1-{ }^{14} \mathrm{C}\right]$-acetic acid, sodium salt, $1 \mathrm{mCi} / \mathrm{mL}(37 \mathrm{MBq} / \mathrm{mL}), 45-60 \mathrm{mCi} / \mathrm{mmol}$. Store at $4^{\circ}$ C. (see Note 4$)$.

5. DMSO (Dimethyl sulfoxide). (see Note 5).

6. TOFA (5-tetradecyloxy-2-furoic acid).stock solution: $10 \mathrm{mM}$ in DMSO. Store at $20^{\circ} \mathrm{C}$. (see Note 6).

7. Metformin, $\mathrm{HCl}$ stock solution: $500 \mathrm{mM}$ in sterile distilled $\mathrm{H}_{2} \mathrm{O}$. Store at $-20^{\circ} \mathrm{C}$. (see Note 7).

8. Compound 991 stock solution: $10 \mathrm{mM}$ in DMSO. Store at $-20^{\circ} \mathrm{C}$. (see Note 8).

9. 1x Phosphate-buffered saline (PBS): $140 \mathrm{mM} \mathrm{NaCl}, 2.6 \mathrm{mM} \mathrm{KCl} ; 2 \mathrm{mM} \mathrm{Na}_{2} \mathrm{HPO}_{4}$, $1.45 \mathrm{mM} \mathrm{KH}_{2} \mathrm{PO}_{4}$.

10. Cell scrapers.

11. Humidified $5 \% \mathrm{CO}_{2}$ incubator at $37^{\circ} \mathrm{C}$.

2.2. Lipid extraction and ${ }^{14} \mathrm{C}$-labelled lipid counting

1. $13 \times 100 \mathrm{~mm}$ borosilicate glass tubes.

2. Polytetrafluoroethylene (PTFE)-lined caps.

3. $40 \%(w / v) \mathrm{KOH}$ in degassed distilled $\mathrm{H}_{2} \mathrm{O}$ (see Note 9).

4. Methanol.

5. Water-saturated petroleum ether (boiling point at $40-60^{\circ} \mathrm{C}$ ) (see Note 10). 
6. Bromophenol blue stock solution: $0.2 \%(\mathrm{w} / \mathrm{v})$ in distilled $\mathrm{H}_{2} \mathrm{O}$.

7. Hydrochloric acid $(\mathrm{HCl})$ fuming $37 \%(12 \mathrm{~N})$. (see Note 11).

8. $5 \mathrm{~mL}$ polyethylene pipette dropper.

9. Vortex

10. Oven at $80^{\circ} \mathrm{C}$.

11. Chemical fume hood.

12. $20 \mathrm{~mL}$ liquid scintillation vials.

13. Liquid scintillation cocktail.

14. Radiometric beta counter.

\section{3- Methods}

3.1. Stimulation of cells

1. Mouse primary hepatocytes plated at a density of $0.4 \times 10^{6}$ cells/well in 6 -well plates are cultured in $1.8 \mathrm{~mL}$ of serum-free hepatocyte culture medium at $37^{\circ} \mathrm{C}$ in an incubator providing saturated humidity and $5 \% \mathrm{CO}_{2}$. (see Notes 1,2 and 3 ).

2. Prepare a 10-fold concentrated mix of radiolabelled tracer in M199 medium sufficient for the number of wells used. Use $1,2 \mu \mathrm{L}\left[1-{ }^{14} \mathrm{C}\right]$-acetic acid $(1.2 \mu \mathrm{Ci})$.with $198.8 \mu$ L M199 medium per well. (see Note 12).

3. Add AMPK activators at various concentrations or equivalent volume of vehicle and $200 \mu \mathrm{L}$ of $10 \mathrm{x}$ tracer mix/well. Wells incubated with $20 \mu \mathrm{M}$ TOFA could serve as positive control of lipid synthesis inhibition. (see Note 6).

4. Incubate exactly for 3 hours at $37^{\circ} \mathrm{C}$ in an incubator providing saturated humidity and $5 \% \mathrm{CO}_{2}$.

3.2. Harvesting and lysing of the cells 
1. Wash the cells 3 times with $2 \mathrm{~mL}$ of ice-cold PBS.

2. Harvest cells by gently scrapping wells in $0.5 \mathrm{~mL}$ of PBS.

3. Transfer to glass tubes containing $1 \mathrm{~mL}$ of $40 \% \mathrm{KOH}$ and $2 \mathrm{~mL}$ of methanol.

4. Rinse wells with $0.5 \mathrm{~mL}$ PBS and combine. Cap the tubes and vortex for 1 minute.

5. Heat at $80^{\circ} \mathrm{C}$ for 1 hour then allow tubes to cool completely at room temperature.

\subsection{Lipid extraction}

\subsubsection{Extraction of non saponifiable lipids (see Notes $\mathbf{1 3}$ and 14)}

1. Add $3 \mathrm{~mL}$ of water-saturated petroleum ether in each tube. (see Notes 15).

2. Cap the tubes and vortex for 1 minute.

3. Centrifuge at $1000 \mathrm{x}$ g for 2 minute to separate aqueous and organic phases (see Note 16).

4. Transfer the upper organic phase with a $5 \mathrm{~mL}$ pipette dropper to $20 \mathrm{~mL}$ scintillation vials.

5. Repeat extraction with $3 \mathrm{~mL}$ of water-saturated petroleum ether and combine the upper phases.

6. Evaporate to dryness the organic extract from scintillation vials under a chemical fume hood. (see Note 17).

7. Add $10 \mathrm{~mL}$ of organic scintillation fluid to the dried residues. Vortex thoroughly to dissolve lipids.

8. Count incorporation of ${ }^{14} \mathrm{C}$ into the non saponifiable fraction. (see Note 18).

\subsubsection{Extraction of saponifiable lipids (see Note 19)}

1. Add $50 \mu \mathrm{L}$ of $2 \%$ bromophenol blue to the lower aqueous fraction from 3.3.1 step 4 . 
2. Perform saponification of lipids by acidifying to the lower aqueous fraction with 700 $\mu \mathrm{L}$ of $37 \% \mathrm{HCl}$ and vortex for 1 minute (see Note 20).

3. Add $3 \mathrm{~mL}$ of water-saturated petroleum ether in each tube. (see Notes 15).

4. Cap the tubes and vortex for $1 \mathrm{~min}$.

5. Centrifuge at $1000 \mathrm{x}$ g for $2 \mathrm{~min}$ to separate aqueous and organic phases (see Note 16).

6. Transfer the upper organic phase with a $5 \mathrm{~mL}$ pipette dropper to new $20 \mathrm{~mL}$ scintillation vials.

7. Repeat extraction with $3 \mathrm{~mL}$ water-saturated petroleum ether and combine the upper phases.

8. Evaporate to dryness the organic extract from scintillation vials under a chemical fume hood. (see Note 17).

9. Add $10 \mathrm{~mL}$ of organic scintillation fluid to the dried residues. Vortex thoroughly to dissolve lipids.

10. Count incorporation of ${ }^{14} \mathrm{C}$ into the saponifiable fraction. (see Note 19).

11. Determine specific activity by counting $50 \mu \mathrm{L}$ of labelled media. (see Note 18).

[Figure 1 near here]

\section{4- Notes}

1. The method for the measurement of lipid synthesis described here can be adapted to other cell types because lipid synthesis is active in most cultured cells. An important point to respect is the number of cells in each well since there is no internal control to normalize data. If the cells studied are available in small numbers, the protocol can be 
adapted to 12 - or 24-well plates. However, we found that the 6-well plate format give better results in term of reproducibility.

Measurement of $\left[1-{ }^{14} \mathrm{C}\right]$-acetate incorporation into lipids is a very sensitive method to assess variations of lipid synthesis induced by AMPK activation or other stimuli.

When this measure is coupled with the use of AMPK-deficient cells such as AMPK $\alpha$ $1 \alpha 2 \mathrm{KO}$ hepatocytes [15], it is a powerful functional test to determine the AMPK dependence on lipid synthesis inhibition induced by various drugs or stimuli (Figure 1),.

2. Medium 199 contains $0.6 \mathrm{mM}$ sodium acetate. If an alternative medium is used, supplement or adjust the sodium acetate concentration to $0.6 \mathrm{mM}$.

3. Dexamethasone is specifically used in primary culture of hepatocytes to limit dedifferentiation [16].

4. We use $\left[1-{ }^{14} \mathrm{C}\right]$-acetic acid, sodium salt from Perkin Elmer (NEC084h001MC). Use of radioactive material requires a legal authorization and needs precautions such as designate and label areas for working with radioactive material, use of a chemical fume hood to handle radioactive sources and wear appropriate personal protective equipment. Radioactive waste requires a specific management.

5. In unstimulated cells, the vehicle (DMSO, ethanol, etc.) should be used as a control.

6. TOFA is a competitive inhibitor of acetyl-CoA carboxylase used as a positive control of lipid synthesis inhibition.

7. Metformin is an indirect AMPK activator which stimulates AMPK activity by increasing intracellular AMP/ATP ratio through inhibition of complex I of the mitochondrial respiratory chain $[17,18]$. 
8. Compound 991 is a small-molecule that directly activates AMPK through an AMPindependent mechanism by binding at the interface between the carbohydrate-binding domain of the regulatory $\beta$ subunit and the catalytic $\alpha$ subunit [19].

9. Distilled $\mathrm{H}_{2} \mathrm{O}$ is degassed under vacuum to remove $\mathrm{CO}_{2}$ and to avoid the formation of $\mathrm{K}_{2} \mathrm{CO}_{3}$.

10. Water-saturated petroleum ether is prepared by mixing one volume of distilled $\mathrm{H}_{2} \mathrm{O}$ with one volume of petroleum ether in a glass bottle. After shaking and decanting, water-saturated petroleum ether corresponds to the upper phase.

11. Concentrated $\mathrm{HCl}$ can be replaced by concentrated $\mathrm{H}_{2} \mathrm{SO}_{4}(12 \mathrm{~N})$.

12. $\left[1-{ }^{14} \mathrm{C}\right]$-labelled acetate concentration in medium is $0.6 \mu \mathrm{Ci} \cdot \mathrm{mL}^{-1}$ and cold acetate concentration is $0.6 \mathrm{mM}$.

13. Non-saponifiable fraction corresponds to neutral lipids, predominantly sterols including cholesterol.

14. Extraction of the non-saponifiable fraction can be skipped (Section 3.3.1 steps 1 to 8) and acidification directly carries out. In this case, extracted lipids after saponification correspond to total lipids (sterols and fatty acids).

15. Petroleum ether is extremely flammable. Precautions should be taken in its handling and storing. Vapours are harmful to eyes, respiratory system and skin. Consequently, this solvent should be handling only under a chemical fume hood and proper personal protective should be wearing as chemical resistant gloves, laboratory coat and safety glasses.

16. Centrifugation may be optional because aqueous and organic phases can separate rapidly after a few minutes of decanting.

17. Evaporation of organic extracts in vials takes several hours. Usually, we keep the uncapped vials under a chemical fume hood overnight. Evaporation can be accelerated 
through the use of an evaporator system which blows down a stream of dry air or nitrogen gas in the vials.

18. Counting are disintegrations per minute (dpm). The blank value obtained from wells without cells but treated as other wells is deducted for each sample. We recommend to perform each condition in triplicate for each experiment. Data are normalized to the protein amount per well. For this, reserve at least a 6-well plate of cells incubated without $\left[1-{ }^{14} \mathrm{C}\right]$-labelled acetate to assess the amount of proteins per well. The results can be expressed as a percentage of basal (unstimulated condition) or in absolute values (nanomoles of $\left[1-{ }^{14} \mathrm{C}\right]$-acetate incorporated/mg of proteins/hour) using the specific activity. Specific activity corresponds to the quantity of radioactivity (in dpm) per nmole of acetate in medium. Specific activity is calculated by dividing the number of total dpm measured per well (in $2 \mathrm{~mL}$ ) by the number of nmoles of acetate per well $(0.60 \mathrm{mM} \times 2 \mathrm{~mL}=1220 \mathrm{nmoles}$, the amount of acetate provided by the tracer is negligible). The value of specific activity thus allows to convert the dpm count values deducted of blank in nmoles of $\left[1-{ }^{14} \mathrm{C}\right]$-acetate incorporated in lipids. By dividing these data by the incubation time ( 3 hours) and the amount of proteins per well (mg), the results can be expressed in nmoles of $\left[1-{ }^{14} \mathrm{C}\right]$-acetate incorporated in lipids/mg of proteins/hour.

19. Saponifiable fraction mainly corresponds to fatty acids.

20. $\mathrm{pH}$ indicator (blue bromophenol) should turn yellow to assure complete saponification. 


\section{References}

1. Hardie DG (2014) AMP-activated protein kinase: maintaining energy homeostasis at the cellular and whole-body levels. Annu Rev Nutr 34:31-55. doi:10.1146/annurev-nutr-071812161148

2. Clarke PR, Hardie DG (1990) Regulation of HMG-CoA reductase: identification of the site phosphorylated by the AMP-activated protein kinase in vitro and in intact rat liver. Embo J 9 (8):2439-2446

3. Carling D, Clarke PR, Zammit VA, Hardie DG (1989) Purification and characterization of the AMP-activated protein kinase. Copurification of acetyl-CoA carboxylase kinase and 3hydroxy-3-methylglutaryl-CoA reductase kinase activities. Eur J Biochem 186 (1-2):129-136

4. Foretz M, Viollet B (2011) Regulation of hepatic metabolism by AMPK. J Hepatol 54 (4):827-829. doi:10.1016/j.jhep.2010.09.014

5. Smith BK, Marcinko K, Desjardins EM, Lally JS, Ford RJ, Steinberg GR (2016) Treatment of nonalcoholic fatty liver disease: role of AMPK. Am J Physiol Endocrinol Metab 311 (4):E730-E740. doi:10.1152/ajpendo.00225.2016

6. Zadra G, Photopoulos C, Tyekucheva S, Heidari P, Weng QP, Fedele G, Liu H, Scaglia N, Priolo C, Sicinska E, Mahmood U, Signoretti S, Birnberg N, Loda M (2014) A novel direct activator of AMPK inhibits prostate cancer growth by blocking lipogenesis. EMBO Mol Med 6 (4):519-538. doi:10.1002/emmm.201302734

7. O'Brien AJ, Villani LA, Broadfield LA, Houde VP, Galic S, Blandino G, Kemp BE, Tsakiridis T, Muti P, Steinberg GR (2015) Salicylate activates AMPK and synergizes with metformin to reduce the survival of prostate and lung cancer cells ex vivo through inhibition of de novo lipogenesis. Biochem J 469 (2):177-187. doi:10.1042/BJ20150122 
8. Xie W, Wang L, Dai Q, Yu H, He X, Xiong J, Sheng H, Zhang D, Xin R, Qi Y, Hu F, Guo S, Zhang K (2015) Activation of AMPK restricts coxsackievirus B3 replication by inhibiting lipid accumulation. J Mol Cell Cardiol 85:155-167. doi:10.1016/j.yjmcc.2015.05.021

9. Cool B, Zinker B, Chiou W, Kifle L, Cao N, Perham M, Dickinson R, Adler A, Gagne G, Iyengar R, Zhao G, Marsh K, Kym P, Jung P, Camp HS, Frevert E (2006) Identification and characterization of a small molecule AMPK activator that treats key components of type 2 diabetes and the metabolic syndrome. Cell metabolism 3 (6):403-416. doi:10.1016/j.cmet.2006.05.005

10. Hunter RW, Foretz M, Bultot L, Fullerton MD, Deak M, Ross FA, Hawley SA, Shpiro N, Viollet B, Barron D, Kemp BE, Steinberg GR, Hardie DG, Sakamoto K (2014) Mechanism of action of compound-13: an alpha1-selective small molecule activator of AMPK. Chem Biol 21 (7):866-879. doi:10.1016/j.chembiol.2014.05.014

11. Fullerton MD, Galic S, Marcinko K, Sikkema S, Pulinilkunnil T, Chen ZP, O'Neill HM, Ford RJ, Palanivel R, O'Brien M, Hardie DG, Macaulay SL, Schertzer JD, Dyck JR, van Denderen BJ, Kemp BE, Steinberg GR (2013) Single phosphorylation sites in Acc1 and Acc2 regulate lipid homeostasis and the insulin-sensitizing effects of metformin. Nat Med 19 (12):1649-1654. doi:10.1038/nm.3372

12. Gomez-Galeno JE, Dang Q, Nguyen TH, Boyer SH, Grote MP, Sun Z, Chen M, Craigo WA, van Poelje PD, MacKenna DA, Cable EE, Rolzin PA, Finn PD, Chi B, Linemeyer DL, Hecker SJ, Erion MD (2010) A Potent and Selective AMPK Activator That Inhibits de Novo Lipogenesis. ACS Med Chem Lett 1 (9):478-482. doi:10.1021/ml100143q

13. Ford RJ, Fullerton MD, Pinkosky SL, Day EA, Scott JW, Oakhill JS, Bujak AL, Smith BK, Crane JD, Blumer RM, Marcinko K, Kemp BE, Gerstein HC, Steinberg GR (2015) Metformin and salicylate synergistically activate liver AMPK, inhibit lipogenesis and improve insulin sensitivity. Biochem J 468 (1):125-132. doi:10.1042/BJ20150125 
14. Ducommun S, Ford RJ, Bultot L, Deak M, Bertrand L, Kemp BE, Steinberg GR, Sakamoto K (2014) Enhanced activation of cellular AMPK by dual-small molecule treatment: AICAR and A769662. Am J Physiol Endocrinol Metab 306 (6):E688-696. doi:10.1152/ajpendo.00672.2013

15. Foretz M, Hebrard S, Leclerc J, Zarrinpashneh E, Soty M, Mithieux G, Sakamoto K, Andreelli F, Viollet B (2010) Metformin inhibits hepatic gluconeogenesis in mice independently of the LKB1/AMPK pathway via a decrease in hepatic energy state. J Clin Invest 120 (7):2355-2369. doi:10.1172/JCI40671

16. Laishes BA, Williams GM (1976) Conditions affecting primary cell cultures of functional adult rat hepatocytes. II. Dexamethasone enhanced longevity and maintenance of morphology. In Vitro 12 (12):821-832

17. Owen MR, Doran E, Halestrap AP (2000) Evidence that metformin exerts its anti-diabetic effects through inhibition of complex 1 of the mitochondrial respiratory chain. Biochem $\mathbf{J} 348$ Pt 3:607-614

18. El-Mir MY, Nogueira V, Fontaine E, Averet N, Rigoulet M, Leverve X (2000) Dimethylbiguanide inhibits cell respiration via an indirect effect targeted on the respiratory chain complex I. The Journal of biological chemistry 275 (1):223-228

19. Xiao B, Sanders MJ, Carmena D, Bright NJ, Haire LF, Underwood E, Patel BR, Heath RB, Walker PA, Hallen S, Giordanetto F, Martin SR, Carling D, Gamblin SJ (2013) Structural basis of AMPK regulation by small molecule activators. Nat Commun 4:3017. doi:10.1038/ncomms4017

\section{Acknowledgement}

Work from the authors was performed within the Département Hospitalo-Universitaire (DHU) AUToimmune and HORmonal diseaseS (AUTHORS) and was supported by grants 
from INSERM, CNRS, Université Paris Descartes, Agence Nationale de la Recherche (ANR) and Société Francophone du Diabète (SFD).

\section{Figure Caption}

Figure 1. Effects of metformin and small-molecule 991 on lipid synthesis rates in WT and AMPK-deficient hepatocytes. After plating, WT and AMPK $\alpha 1 \alpha 2$ knockout primary hepatocytes were cultured for 16 hours in serum-free M199 medium containing antibiotics and $100 \mathrm{nM}$ dexamethasone. Hepatocytes were then incubated for 3 hours in fresh medium in the absence or in the presence of increasing concentrations of metformin $(0.25,0.5,1$ or 2 $\mathrm{mM})$, a indirect AMPK activator, or $991(0.1,0.3,1,3$ or $10 \mu \mathrm{M})$, a small-molecule direct activator of AMPK, or TOFA $(20 \mu \mathrm{M})$, a competitive inhibitor of acetyl-CoA carboxylase and $\left[1-{ }^{14} \mathrm{C}\right]$-acetate tracer was added directly in medium. Rates of fatty acid and sterol synthesis were assessed from incorporation of $\left[1-{ }^{14} \mathrm{C}\right]$-acetate into saponifiable $(\mathbf{A})$ and nonsaponifiable (B) lipids respectively. Results were normalized to protein content and presented as a percentage of $\left[1-{ }^{14} \mathrm{C}\right]$-acetate incorporated in WT or AMPK KO hepatocytes incubated in the absence of compounds. Results are representative of three independent experiments. Data are mean \pm SEM. ${ }^{*} P<0.05,{ }^{* *} P<0.001$ compared with WT or AMPK KO hepatocytes incubated in the absence of compounds and ${ }^{\S} P<0.01,{ }^{\S \S} P<0.001$ compared with WT hepatocytes incubated in the same conditions by two-way ANOVA with Bonferroni post hoc test. Whilst TOFA inhibits lipid synthesis both in WT and AMPK-deficient hepatocytes, metformin and 991 inhibit $\left[1-{ }^{14} \mathrm{C}\right]$-acetate incorporation in lipids in concentration-dependent manner only in WT hepatocytes. These results demonstrate that the inhibition of hepatic lipid synthesis in response to metformin and 991 is strictly dependent of AMPK. 


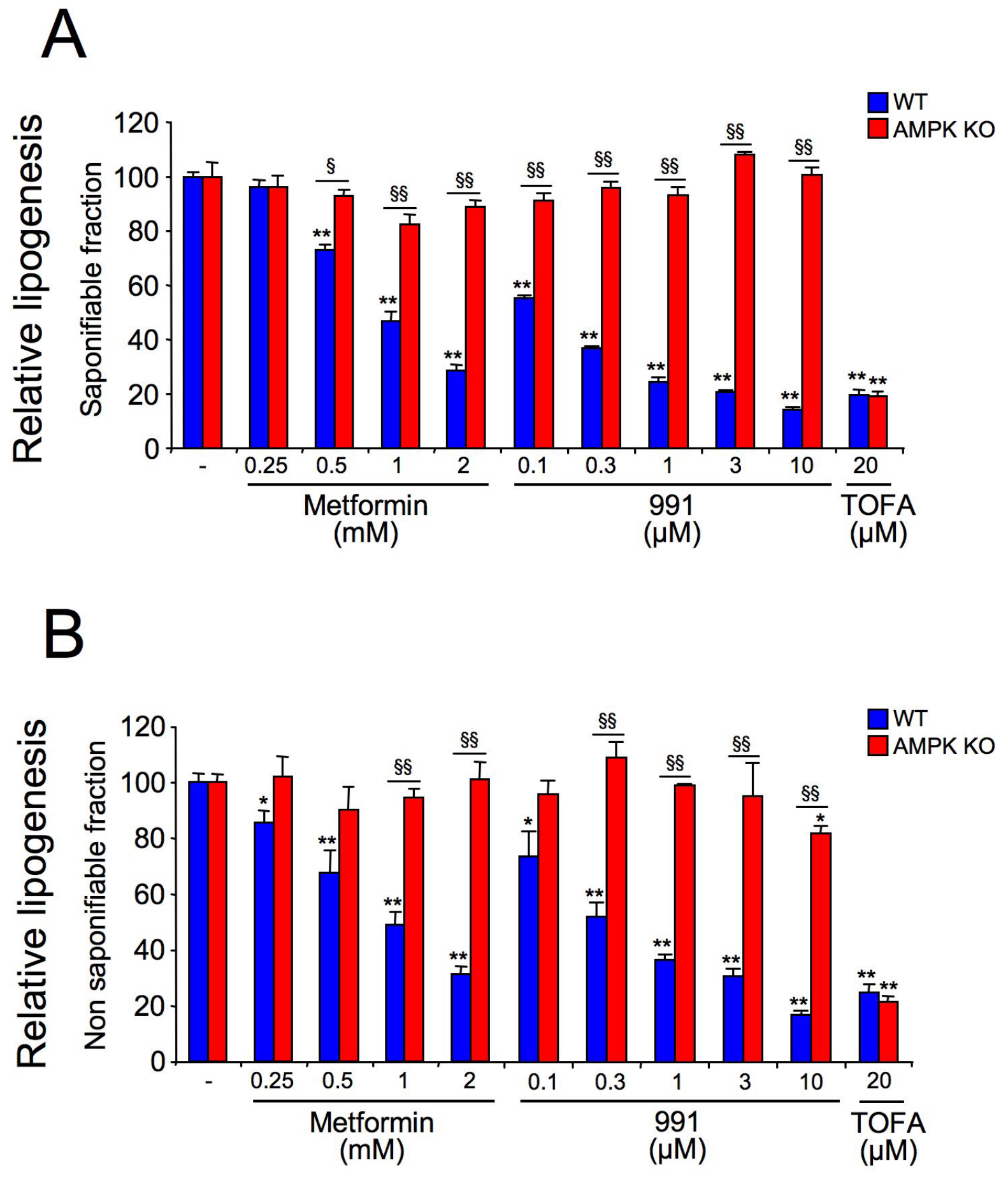

